\title{
Fertility of lactating Holstein cows submitted to a Double-Ovsynch protocol and timed artificial insemination versus artificial insemination after synchronization of estrus at a similar day in milk range
}

\author{
V. G. Santos, ${ }^{*}$ P. D. Carvalho, ${ }^{*}$ C. Maia,† B. Carneiro,† A. Valenza, $\ddagger$ and P. M. Fricke ${ }^{* 1}$ \\ *Department of Dairy Science, University of Wisconsin, Madison 53706 \\ †Diessen Serviços Veterinários Lda, 7001 Évora, Portugal \\ ¥Ceva Santé Animale, 10 Avenue de la Ballastiere, 33500 Libourne, France
}

\begin{abstract}
Our objective was to compare the AI submission rate and pregnancies per artificial insemination $(\mathrm{P} /$ AI) at first service of lactating Holstein cows submitted to a Double-Ovsynch protocol and timed artificial insemination (TAI) versus artificial insemination (AI) to a detected estrus after synchronization of estrus at a similar day in milk range. Lactating Holstein cows were randomly assigned to receive their first TAI after a Double-Ovsynch protocol (DO; $\mathrm{n}=294)$ or to receive their first AI after a synchronized estrus (EST; $\mathrm{n}=$ 284). Pregnancy status was determined $33 \pm 3 \mathrm{~d}$ after insemination and was reconfirmed $63 \pm 3 \mathrm{~d}$ after insemination. Data were analyzed by ANOVA and logistic regression using the MIXED and GLIMMIX procedures of SAS (SAS Institute Inc., Cary, NC). By design, days in milk at first insemination did not differ between treatments $(76.9 \pm 0.2$ vs. $76.7 \pm 0.3$ for DO vs. EST cows, respectively), but more DO cows were inseminated within $7 \mathrm{~d}$ after the end of the voluntary waiting period than EST cows (100.0 vs. $77.5 \%$ ). Overall, DO cows had more P/AI than EST cows at both $33 \mathrm{~d}(49.0$ vs. $38.6 \%)$ and $63 \mathrm{~d}(44.6$ vs. $36.4 \%)$ after insemination, but pregnancy loss from 33 to $63 \mathrm{~d}$ after insemination did not differ between treatments. Primiparous cows had more P/AI than multiparous cows 33 and $63 \mathrm{~d}$ after insemination, but the treatment by parity interaction was not significant. Synchronization rate to the hormonal protocols was $85.3 \%$, which did not differ between treatments; however, synchronized DO cows had more P/AI $33 \mathrm{~d}$ after insemination than synchronized EST cows (54.7 vs. $44.5 \%$ ). In summary, submission of lactating Holstein cows to a Double-Ovsynch protocol and TAI for first insemination increased the percentage of cows inseminated within $7 \mathrm{~d}$ after the end of the vol-
\end{abstract}

Received May 22, 2017.

Accepted June 22, 2017

${ }^{1}$ Corresponding author: pmfricke@wisc.edu untary waiting period and increased P/AI at 33 and 63 $\mathrm{d}$ after first insemination resulting in 64 and $58 \%$ more pregnant cows, respectively, than submission of cows for first AI after detection of estrus at a similar day in milk range. We conclude that, because the proportion of synchronized cows did not differ between treatments, DO cows had more P/AI than EST cows because of an intrinsic increase in fertility after submission to a fertility program.

Key words: first artificial insemination, timed artificial insemination, estrus, fertility

\section{INTRODUCTION}

Hormonal synchronization protocols that allow for timed artificial insemination (TAI) have been incorporated widely into reproductive management programs by dairy farms (Caraviello et al., 2006; Norman et al., 2009); however, AI based on detection of estrus continues to be an important part of the overall reproductive management program on most dairy farms (Caraviello et al., 2006; Miller et al., 2007). Results from the first field trial evaluating the Ovsynch protocol on a commercial dairy farm reported that Ovsynch and TAI yielded similar pregnancies per artificial insemination $(\mathbf{P} / \mathbf{A I})$ to that of cows receiving AI after a detected estrus (39 vs. 37\%; Pursley et al., 1997) but that median days to first AI (54 vs. 83) and days open (99 vs. 118) were decreased for cows submitted for first insemination using an Ovsynch protocol than for cows submitted for AI after a detected estrus, respectively. Thus, the initial effect of TAI protocols on 21-d pregnancy rates in US dairy herds was to increase the AI service rate, with little to no effect on $\mathrm{P} / \mathrm{AI}$ (Norman et al., 2009).

Since the development of the Ovsynch protocol by Pursley et al. (1995), several modifications to the original Ovsynch protocol have been tested in an attempt to increase $\mathrm{P} / \mathrm{AI}$ to TAI. These modifications include increasing ovulatory response to the first $\mathrm{GnRH}$ treat- 
ment (Carvalho et al., 2015b), presynchronization using $2 \mathrm{PGF}_{2 \alpha}$ treatments (i.e., Presynch-Ovsynch; Moreira et al., 2001; Navanukraw et al., 2004; Ribeiro et al., 2011), presynchronization using a combination of $\mathrm{GnRH}$ and PGF $_{2 \alpha}$ (i.e., G-6-G and Double-Ovsynch; Bello et al., 2006; Souza et al., 2008; Carvalho et al., 2014a), and addition of a second $\mathrm{PGF}_{2 \alpha}$ treatment $24 \mathrm{~h}$ after the first within the Ovsynch protocol to induce complete luteal regression (Carvalho et al., 2015a; Wiltbank et al., 2015; Santos et al., 2016). Taken together, these modifications have yielded $\mathrm{P} / \mathrm{AI}$ at first service that exceed $50 \%$ in high-producing Holstein cows (Carvalho et al., 2014a, 2015b). Thus, the latest iterations of hormonal synchronization protocols for submitting lactating dairy cows for first service can be best described as fertility programs for high-producing dairy cows because all cows can be inseminated within $7 \mathrm{~d}$ of the end of the voluntary waiting period and yielding more $\mathrm{P} / \mathrm{AI}$ at first service.

The idea that fertility programs and TAI can yield greater fertility than AI to estrus at first insemination in high-producing dairy cows has not been definitively tested. Several experiments compared P/AI of cows inseminated after TAI with cows inseminated after a detected estrus at first AI, with some studies reporting no differences in P/AI (Pursley et al., 1997; Chebel and Santos, 2010; Dolecheck et al., 2016), whereas others reported more $\mathrm{P} / \mathrm{AI}$ for cows receiving TAI (Gumen et al., 2012; Fricke et al., 2014; Stevenson et al., 2014). In all of these studies, however, DIM at first service differed between cows submitted to TAI and cows submitted to AI after a detected estrus. Further, DIM is a clear confounder because cows with more DIM at first service have more time for uterine involution and for resumption of cyclicity, both of which affect $\mathrm{P} / \mathrm{AI}$ (Buch et al., 1955; Chebel and Santos, 2010).

Our objective was to compare the AI submission rate and $\mathrm{P} / \mathrm{AI}$ at first service of lactating Holstein cows submitted to a Double-Ovsynch protocol and TAI versus AI to a detected estrus after synchronization of estrus at a similar DIM range. Our hypothesis was that the AI submission rate and $\mathrm{P} / \mathrm{AI}$ at first service would be greater for cows submitted to first TAI after a DoubleOvsynch protocol than for cows receiving AI to a detected estrus after submission to a hormonal protocol for synchronization of estrus.

\section{MATERIALS AND METHODS}

All animal handling and experimental procedures were approved by the Animal Care and Use committee of the College of Agriculture and Life Sciences at the University of Wisconsin-Madison.

\section{Cows, Housing, and Feeding}

This study was conducted from October 2015 to June 2016 on 1 commercial dairy farm in Portugal. Lactating Holstein cows $(\mathrm{n}=578)$ were milked twice daily at approximately $12-\mathrm{h}$ intervals. Cows were fed twice daily a TMR consisting of corn silage and alfalfa hay as forage with corn and soybean meal-based concentrate formulated to meet or exceed the minimum nutritional requirements for high-producing dairy cows (NRC, 2001). Cows were housed in freestall barns bedded with mattress and had ad libitum access to feed and water. Primiparous and multiparous cows were housed in separate pens, and barns were equipped with fans and sprinklers that were automatically activated when the temperature inside the barns exceeded 28 and $32^{\circ} \mathrm{C}$, respectively. The rolling herd average and daily milk production were $10,719 \mathrm{~kg}$ and $35.6 \mathrm{~kg} / \mathrm{cow}$ per day with $4.9 \%$ fat and $3.3 \%$ protein during the experiment.

\section{Experimental Treatments}

Each week, cows at $50 \pm 3$ DIM (d 0) were stratified by parity (primiparous vs. multiparous) and were randomly assigned to 2 treatments to receive first insemination (Figure 1$)$. Cows $(\mathrm{n}=294)$ in the first treatment were submitted for first TAI after a modified DoubleOvsynch (DO) protocol that included a second $\mathrm{PGF}_{2 \alpha}$ treatment $24 \mathrm{~h}$ after the first in the Breeding-Ovsynch portion of the protocol. Briefly, on d 0 cows received the first GnRH treatment of the Pre-Ovsynch portion of the Double-Ovsynch protocol, followed by treatment with $\mathrm{PGF}_{2 \alpha} 7 \mathrm{~d}$ later and $\mathrm{GnRH} 72 \mathrm{~h}$ after $\mathrm{PGF}_{2 \alpha}$. Seven days later, cows received a GnRH treatment followed by $2 \mathrm{PGF}_{2 \alpha}$ treatments administered 7 and $8 \mathrm{~d}$ later, with the last $\mathrm{GnRH}$ treatment administered 56 $\mathrm{h}$ after the first $\mathrm{PGF}_{2 \alpha}$ treatment followed by TAI 16 to $20 \mathrm{~h}$ later. Cows $(\mathrm{n}=284)$ in the second treatment were submitted to a hormonal synchronization protocol for synchronization of estrus and were inseminated if detected in estrus (EST). Briefly, 3 d after d 0 (Figure 1 ), cows were treated with GnRH followed by treatment with $\mathrm{PGF}_{2 \alpha} 7 \mathrm{~d}$ later. Fourteen days later, cows received $2 \mathrm{PGF}_{2 \alpha}$ treatments administered $24 \mathrm{~h}$ apart. Cows detected in estrus from $2 \mathrm{~d}$ before until $7 \mathrm{~d}$ after the first of the $2 \mathrm{PGF}_{2 \alpha}$ treatments at the end of the protocol were inseminated within $12 \mathrm{~h}$ of detection of estrus based on visual detection of estrus, which was aided using pedometers attached to the rear legs of the cows (Westfalia Separator, GEA, Lisbon, Portugal).

The GnRH $(100 \mu \mathrm{g} /$ dose of gonadoreline diacetate tetrahydrate, Ovarelin) and the $\mathrm{PGF}_{2 \alpha}(25 \mathrm{mg} /$ dose of dinoprost tromethamine, Enzaprost-T) used in this 
experiment were from Ceva Santé Animale (Libourne, France). Four high fertility sires, with a sire conception rate $>0$ and more than 6,000 observations each, were used for insemination, and sires were equally balanced between treatments. Cows were inseminated by 2 farm personnel, and inseminations were equally balanced between inseminators and treatments. Sires 1, 2, 3, and 4 were used in 24.1, 23.8, 24.5, and $27.6 \%$ of the inseminations for cows in the DO treatment and in 27.7, $24.5,23.6$, and $24.1 \%$ of the inseminations for cows in the EST treatment.

\section{Blood Sampling and Progesterone Assay}

Blood samples were collected from all cows via puncture of the median caudal blood vessels into 8-mL evacuated serum collection tubes (Vacuette, Greiner Bio-One North America Inc., Monroe, NC). Blood samples were collected on the day of enrollment (d 0) immediately before administration of any hormonal treatments, before treatment with $\mathrm{PGF}_{2 \alpha}$ (d 24), at the last GnRH treatment for $\mathrm{DO}$ cows or on the day of AI for EST cows, and $7 \mathrm{~d}$ after the last $\mathrm{GnRH}$ treatment for DO cows or $7 \mathrm{~d}$ after AI for EST cows (Figure $1)$. After collection, blood samples were refrigerated until centrifuged $\left(20 \mathrm{~min}\right.$ at $\left.1,600 \times g ; 4^{\circ} \mathrm{C}\right)$. Serum was harvested and stored at $-20^{\circ} \mathrm{C}$ until assayed for progesterone (P4) concentrations using a chemiluminescent assay (Immulite, Siemens, Wales, UK). Average sensitivity for the 8 assays was $<0.2 \mathrm{ng} / \mathrm{mL}$. Average intraassay and interassay coefficients of variation were 6.3 and $4.9 \%$, respectively, based on a quality control sample $(2.50 \mathrm{ng} / \mathrm{mL}$ of $\mathrm{P} 4)$ that was replicated within each assay.

\section{Pregnancy Diagnosis}

Pregnancy diagnosis was performed $33 \pm 3$ d after AI using a portable scanner (Easi-Scan, BCF Technology Ltd., Livingston, UK) equipped with a $7.5-\mathrm{MHz}$ linear-array transducer. A positive pregnancy diagnosis was based on visualization of a corpus luteum (CL) on the ovary ipsilateral to the uterine horn containing an embryo with a heartbeat. Pregnancy status for cows diagnosed pregnant at the first examination was reconfirmed $63 \pm 3 \mathrm{~d}$ after AI using the same ultrasound machine and transducer. Cows diagnosed pregnant and subsequently diagnosed not pregnant at the pregnancy reconfirmation were classified as having undergone pregnancy loss.

\section{BCS Evaluation and Milk Yield}

Body condition score was evaluated for all cows on the day of the last $\mathrm{PGF}_{2 \alpha}$ treatment of each protocol using a 5 -point scale with 0.25 increments where $1=$ thin and 5 = fat (Ferguson et al., 1994). One person performed all BCS evaluations throughout the experiment. Based on a previous study (Carvalho et al., 2014b), BCS were categorized as either low $(\leq 2.50)$ or high $(\geq 2.75)$ for statistical analysis.

Milk weights for the $7 \mathrm{~d}$ before the last $\mathrm{PGF}_{2 \alpha}$ treatment of each protocol were recorded daily and stored in the on-farm computer software program (BoviSync, Dairy LLC, Eden, WI). For statistical analysis, average milk weights of the $7 \mathrm{~d}$ before insemination were used, and cows were categorized by parity (primiparous vs. multiparous) according to milk production as being greater than or less than mean milk production.
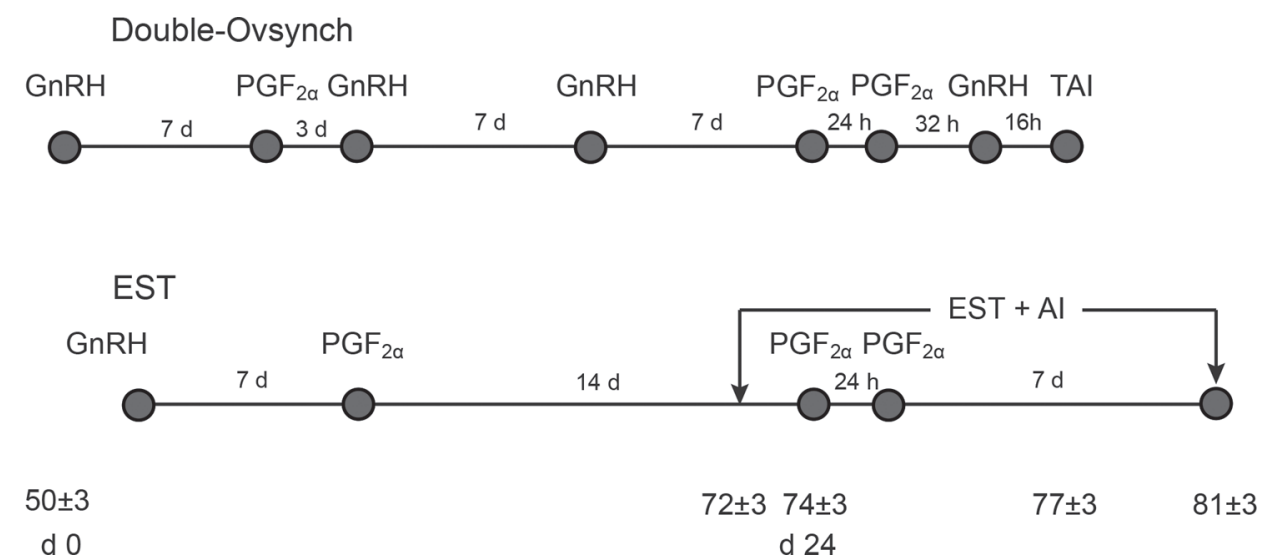

Figure 1. Schematic diagram of treatments and experimental endpoints. Each week, lactating Holstein cows at $50 \pm 3$ DIM (d 0) were stratified by parity (primiparous vs. multiparous) and randomly assigned to receive their first insemination as a timed artificial insemination (TAI) after a Double-Ovsynch (DO) protocol or as an AI to a detected estrus after a protocol for synchronization of estrus (EST). 


\section{Statistical Analyses}

The experimental design was a completely randomized design balanced by parity (primiparous vs. multiparous) as the stratifying factor. All statistical analyses were performed using SAS computational software, version 9.4 for Microsoft Windows (SAS Institute Inc., Cary, NC).

Analysis of binary response data $(\mathrm{P} / \mathrm{AI}$, pregnancy loss, pregnancy rate, percentage of cows with low $(\leq 2.5)$ BCS near AI, \% of cows inseminated, synchronization rate) was performed by logistic regression using the GLIMMIX procedure of SAS. Fixed effects included in the initial models were treatment, parity, level of milk production, and BCS category [except for analysis of $\%$ of cows with low $(\leq 2.5)$ BCS near AI]. Selection of the fixed effects model that best fit the data for each variable of interest was performed by finding the model with the lowest value for the Akaike information criterion using a backward elimination procedure that removed from the model all variables with a $P$-value exceeding 0.10. Effects of treatment and parity were forced to remain in the statistical model; parity was forced to remain the final model because it was used as a stratifying factor when randomizing cows to treatments. The final models included the fixed effects of treatment and parity. For P/AI and pregnancy loss, BCS category was also included in the final model. The effect of $\mathrm{P} 4$ concentration at $\mathrm{d} 0$ on $\mathrm{P} / \mathrm{AI}$ was analyzed using the GLIMMIX procedure of SAS using a model that contained only the fixed effect of $\mathrm{P} 4$ category. The distribution of DIM at insemination was performed using the LOGISTIC procedure of SAS with a model containing the fixed effects of treatment and parity.

Differences in milk production, BCS, average DIM, and $\mathrm{P} 4$ concentrations were determined by ANOVA using the MIXED procedure of SAS. The model contained the fixed effects of treatment, parity, and the treatment $\times$ parity interaction. Cows were distributed into 9 categories using $\mathrm{P} 4$ concentrations on d 0 and 24 (from 0.0 to $\geq 7.0 \mathrm{ng} / \mathrm{mL}$ ), and into 5 categories using
$\mathrm{P} 4$ concentrations near insemination (from 0.0 to $\geq 0.5$ $\mathrm{ng} / \mathrm{mL}$ ) and $7 \mathrm{~d}$ after insemination (from 0.0 to $\geq 4.0$ $\mathrm{ng} / \mathrm{mL}$ ). Differences in the proportion of cows within each P4 category were analyzed by logistic regression using the LOGISTIC procedure of SAS.

A significant difference between the levels of a classification variable was considered when $P \leq 0.05$, whereas differences between $P>0.05$ and $P \leq 0.10$ were considered a statistical tendency.

\section{RESULTS AND DISCUSSION}

\section{Milk Production and BCS}

To test whether cows were appropriately randomized to treatments, we compared milk production and BCS of cows between treatments (Table 1). Average milk production of cows during the $7 \mathrm{~d}$ preceding insemination did not differ $(P=0.72)$ between treatments; however, primiparous cows produced less $(P<0.01)$ milk than multiparous cows $(35.3$ vs. $44.9 \mathrm{~kg} / \mathrm{d}$, respectively). Average BCS did not differ $(P=0.85)$ between treatments; however, BCS was greater $(P<0.01)$ for primiparous than multiparous cows (2.98 vs. 2.78 , respectively). The proportion of cows with low $(\leq 2.50)$ BCS did not differ $(P=0.54)$ between treatments, and fewer $(P<0.01)$ primiparous cows had low $(\leq 2.50)$ BCS than multiparous cows $[7.0 \%(15 / 215)$ vs. $30.9 \%$ $(112 / 363)$, respectively].

\section{Effect of Treatment on DIM at Insemination and Submission Rate}

Several experiments have compared P/AI at first AI for cows inseminated after synchronization of ovulation and TAI with cows receiving AI after a detected estrus, with some studies reporting no differences in P/AI (Pursley et al., 1997; Chebel and Santos, 2010; Dolecheck et al., 2016), whereas others reported more P/AI for cows receiving TAI (Gumen et al., 2012; Fricke et al., 2014; Stevenson et al., 2014). In all of

Table 1. Mean $( \pm$ SEM) milk production and BCS of lactating Holstein cows enrolled in the experiment

\begin{tabular}{|c|c|c|c|}
\hline \multirow[b]{2}{*}{ Item } & \multicolumn{2}{|c|}{ Treatment $^{1}$} & \multirow[b]{2}{*}{$P$-value } \\
\hline & DO & EST & \\
\hline $\mathrm{n}$ & 294 & 284 & - \\
\hline Milk production $(\mathrm{kg} / \mathrm{d})$ & $41.4 \pm 0.5$ & $41.3 \pm 0.5$ & 0.72 \\
\hline BCS & $2.85 \pm 0.02$ & $2.85 \pm 0.02$ & 0.84 \\
\hline Cows with $\mathrm{BCS} \leq 2.50$ at $\mathrm{PGF}_{2 \alpha}, \%$ (no. $/$ no.) & $19.0(56 / 294)$ & $25.0(71 / 284)$ & 0.54 \\
\hline Cows with $\mathrm{P} 4<0.5$ at enrollment, $\%$ (no./no.) & $26.8(78 / 291)$ & $27.4(204 / 281)$ & 0.88 \\
\hline
\end{tabular}


these studies, however, DIM at which insemination occurred differed for cows submitted to TAI versus cows submitted to AI after a detected estrus. For example, in the study by Pursley et al. (1997), cows receiving TAI were inseminated with fewer DIM than cows receiving AI after estrus detection (54 vs. 83 DIM, respectively). Similarly, in the study by Dolecheck et al. (2016) cows receiving TAI were inseminated earlier after the voluntary waiting period than cows inseminated after detection of estrus ( 6 vs. $17 \mathrm{~d}$, respectively). By contrast, in the studies by Chebel and Santos (2010), Fricke et al. (2014), and Stevenson et al. (2014), cows submitted to TAI had more DIM than cows submitted to AI after detection of estrus ( 74 vs. 65 DIM in the study by Chebel and Santos, 2010; 75 vs. 59 DIM in the study by Fricke et al., 2014; and 75 vs. 65 DIM in the study by Stevenson et al., 2014).

The experimental design used in the present experiment allowed us to compare the AI submission rate of cows inseminated at a similar DIM range, which was a primary objective of the experiment. By design, average DIM at first insemination did not differ $(P=0.37)$ between treatments (76.9 vs. $76.7 \mathrm{~d}$ for DO and EST cows, respectively). In addition, distribution of DIM at which cows were inseminated did not differ between treatments (Figure 2; lower panel). The AI submission rate was greater $(P<0.01)$ for DO than for EST cows [100\% (294/294) vs. $77.5 \%$ (220/284); Figure 2; upper panel], but the proportion of cows inseminated did not differ $(P=0.64)$ between parities $[91.2 \%(196 / 215)$ vs. $87.6 \%$ (318/363) for primiparous vs. multiparous cows, respectively].

Because the rate of anovulation assessed in 5,818 lactating Holstein cows from 13 studies in 8 herds averaged $23.3 \%$ (Bamber et al., 2009), we attempted to decrease the proportion of anovular EST cows by initiating the synchronization of estrus protocol with a $\mathrm{GnRH}$ treatment (Figure 1), which induced ovulation in $88 \%$ of anovular cows in another study (Gümen et al., 2003). In our study, estrus detection was performed by visual observation of cows standing to be mounted by herdmates and was aided using a pedometry system that resulted in a 77.5\% AI submission rate. By comparison, AI submission rates of lactating Holstein cows based on detection of increased activity using an activity monitoring system were 69 to $70 \%$ after $2 \mathrm{PGF}_{2 \alpha}$ treatments administered $14 \mathrm{~d}$ apart (Fricke et al., 2014), and $71 \%$ for cows treated with $\mathrm{GnRH}$ followed by $\mathrm{PGF}_{2 \alpha}$ 7 d later (Valenza et al., 2012). Thus, although 70 to $80 \%$ AI submission rates can be achieved using visual detection of estrus, pedometry, or activity monitoring systems, they do not approach the $100 \%$ AI submission rate achieved for cows submitted to a fertility program and TAI for first insemination.

\section{Effect of Treatment on Pregnancies per Al and Pregnancy Loss}

In support of our hypothesis, DO cows had $27 \%$ more $(P=0.02)$ pregnancies than EST cows $33 \mathrm{~d}$ after insemination (Table 2 ). In addition, primiparous cows had more $(P<0.01) \mathrm{P} /$ AI than multiparous cows $[54.6 \%$ $(107 / 196)$ vs. $38.4 \%(122 / 318)]$, but the treatment by parity interaction on $\mathrm{P} / \mathrm{AI} 33 \mathrm{~d}$ after insemination was not significant $[57.3 \%(63 / 110)$ and $44.0 \%(81 / 184)$ for primiparous vs. multiparous DO cows; $51.2 \%$ (44/86) and $30.6 \%$ (41/134) for primiparous vs. multiparous EST cows, respectively]. The effect of treatment on P/ AI was maintained at the pregnancy reconfirmation with DO cows having $23 \%$ more $(P=0.05)$ pregnancies than EST cows $63 \mathrm{~d}$ after insemination (Table 2). In addition, primiparous cows had more $(P<0.01) \mathrm{P} /$ AI than multiparous cows $[51.0 \%(100 / 196)$ vs. $34.9 \%$ $(111 / 318)]$, but no treatment by parity interaction

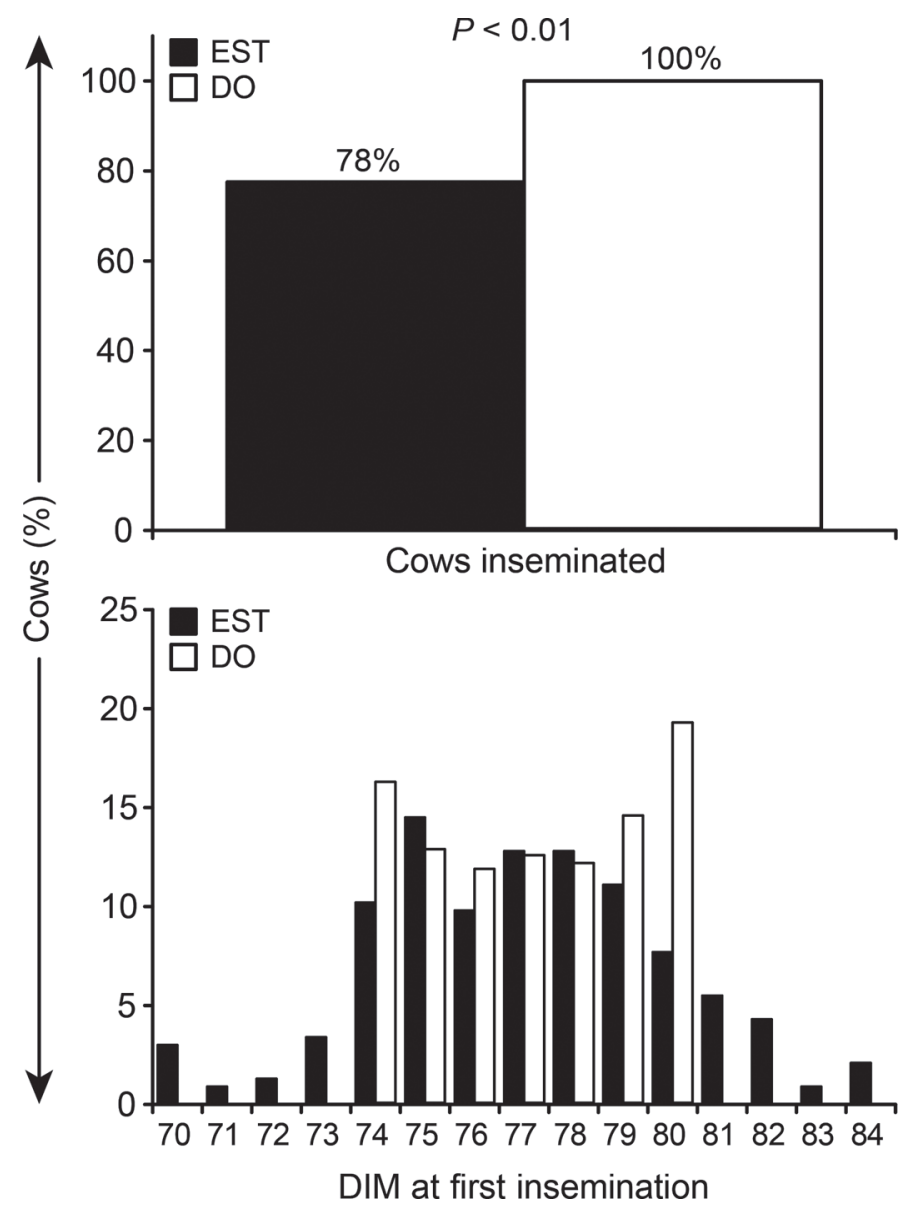

Figure 2. Effect of treatment on proportion of lactating Holstein cows inseminated (upper panel) and DIM at insemination (lower panel). DO $=$ first insemination as a timed AI after a Double-Ovsynch protocol; EST $=$ first insemination as an AI to a detected estrus after a protocol for synchronization of estrus. 
Table 2. Effect of treatment on submission rate, pregnancies per AI (P/AI) 33 and $63 \mathrm{~d}$ after insemination, and percentage of pregnant cows at 33 and $63 \mathrm{~d}$ after insemination in lactating Holstein cows

\begin{tabular}{lccc}
\hline & \multicolumn{2}{c}{ Treatment $^{1}$} & \\
\cline { 2 - 3 } Item & DO & EST & $\begin{array}{c}\text { Difference, } \\
(P \text {-value })\end{array}$ \\
\hline No. of cows & 294 & 284 & \\
Submission rate, \% (no./no.) & $100.0(294 / 294)$ & $77.5(220 / 284)$ & $29(<0.01)$ \\
P/AI at 33 d, \% (no./no.) & $49.0(144 / 294)$ & $38.6(85 / 220)$ & $27(0.02)$ \\
Pregnant cows at 33 d, \% (no./no.) & $49.0(144 / 294)$ & $29.9(85 / 284)$ & $64(<0.01)$ \\
P/AI at 63 d, \% (no./no.) & $44.6(131 / 294)$ & $36.4(80 / 220)$ & $23(0.05)$ \\
Pregnant cows at 63 d, \% (no./no.) & $44.6(131 / 294)$ & $28.2(80 / 284)$ & $58(<0.01)$ \\
\hline${ }^{1}$ Each week, lactating Holstein cows at $50 \pm$ 3 DIM (d 0) were stratified by parity (primiparous vs. multipa- \\
rous) and were randomized to receive first insemination as a timed AI after a Double-Ovsynch (DO) protocol \\
or AI to a detected estrus after a hormonal protocol that synchronized estrus (EST). \\
${ }^{2}$ Relative difference due to treatment for each item was calculated as the difference between DO and EST cows \\
divided by EST cows.
\end{tabular}

was observed on P/AI $63 \mathrm{~d}$ after insemination [52.7\% $(58 / 110)$ and $39.7 \%(73 / 184)$ for primiparous and multiparous DO cows; $48.8 \%(42 / 86)$ and $28.4 \%(38 / 134)$ for primiparous and multiparous EST cows].

Submission of cows for first insemination using a fertility program such as the Double-Ovsynch protocol used in the present study yielded not only a greater AI submission rate, but $23 \%$ more $\mathrm{P} / \mathrm{AI}$ than submission of cows to AI after a detected estrus at a similar DIM range. Taken together, the increased submission rate and $\mathrm{P} / \mathrm{AI}$ for DO cows in the present study yielded $64 \%$ more pregnant cows at $33 \mathrm{~d}$ after insemination and $58 \%$ more pregnant cows at $63 \mathrm{~d}$ after insemination than EST cows (Table 2). A recent meta-analysis of 3 controlled studies that included 1,689 cows reported that incorporation of insemination of cows to estrus after the second $\mathrm{PGF}_{2 \alpha}$ treatment of a Presynch-Ovsynch protocol decreased the odds of pregnancy by $35 \%$ compared with $100 \%$ TAI after a Presynch-Ovsynch protocol (Borchardt et al., 2016). Taken together, results from Borchardt et al. (2016) and from the present study support that insemination of high-producing Holstein cows after a detected estrus results in lower fertility than when ovarian function and timing of $\mathrm{AI}$ is manipulated during a fertility program such as the Double-Ovsynch protocol used in the present study followed by TAI.

In agreement with another study (Carvalho et al., $2014 \mathrm{~b})$, cows in the present experiment with BCS $\leq 2.5$ had fewer $(P<0.01) \mathrm{P} / \mathrm{AI}$ than cows with BCS $\geq 2.75$ $[29.1 \%(30 / 103)$ vs. $48.4 \%(199 / 411)]$. Cows with BCS $\leq 2.5$ had fewer $(P=0.02) \mathrm{P} / \mathrm{AI}$ than cows with BCS $\geq 2.75[27.2 \%(28 / 103)$ vs. $44.5 \%(183 / 411)]$. Pregnancy loss from 33 to $63 \mathrm{~d}$ after AI did not differ $(P=0.43)$ between treatments $[9.0 \%(13 / 144)$ vs. $5.9 \%(5 / 85)$ for DO vs. EST cows, respectively $]$ or between parities $[P$ $=0.47 ; 6.5 \%(7 / 107)$ vs. $9.0 \%(11 / 122)$ for primiparous vs. multiparous cows, respectively]. In addition, pregnancy loss did not differ $(P=0.67)$ between BCS categories $[6.7 \%(2 / 30)$ vs. $8.0 \%(16 / 199)$, for BCS $\leq 2.5$ vs. BCS $\geq 2.75$, respectively]. A larger sample size would be required to perform a valid comparison of the effects of treatment or parity on pregnancy loss in the present study.

\section{Progesterone Profiles}

Blood samples were collected at d 0 to determine $\mathrm{P} 4$ status at the onset of the synchronization protocols and at $\mathrm{d} 24$ of the protocols (Figure 1), at insemination, and $7 \mathrm{~d}$ later to assess timing of AI and to determine the proportion of cows synchronized during the protocols.

$P$ 4 at $\boldsymbol{d} \boldsymbol{0}$. Mean $\mathrm{P} 4$ concentration at $\mathrm{d} 0$ was 2.8 $\pm 0.1 \mathrm{ng} / \mathrm{mL}$ and did not differ $(P=0.71)$ between treatments (2.8 vs. $2.8 \mathrm{ng} / \mathrm{mL}$, for DO vs. EST cows, respectively), and primiparous cows tended $(P=0.07)$ to have lower $\mathrm{P} 4$ concentrations than multiparous cows ( 2.5 vs. $2.9 \mathrm{ng} / \mathrm{mL}$, respectively). As expected, the distribution of cows based on $\mathrm{P} 4$ concentrations on the day of enrollment did not differ between treatments (Figure 3, upper left panel). Overall, the proportion of cows with $\mathrm{P} 4<0.5 \mathrm{ng} / \mathrm{mL}$ on d 0 was $27.1 \%(155 / 572)$ and did not differ $(P=0.88)$ between treatments (Table 1; Figure 3, upper left panel). Cows with $<0.5 \mathrm{ng} /$ $\mathrm{mL}$ of $\mathrm{P} 4$ at the onset of the protocols should consist of anovular cows in addition to a few cycling cows at a stage of the estrous cycle when $\mathrm{P} 4$ would normally be low. In support of this idea, more $(P=0.03)$ primiparous cows had $\mathrm{P} 4<0.5 \mathrm{ng} / \mathrm{mL}$ than multiparous cows $[31.9 \%(68 / 213)$ vs. $24.2 \%(87 / 359)$, respectively], which agrees with data from other studies in which primiparous cows had a greater incidence of anovulation than multiparous cows (Gümen et al., 2003; Santos et al., 2004; Silva et al., 2007).

$P_{4}$ at d $\mathrm{O}$ for EST Cows Not Detected in Estrus. Estrus cows not detected in estrus at the end of the protocol were further analyzed (Figure 4). Mean 


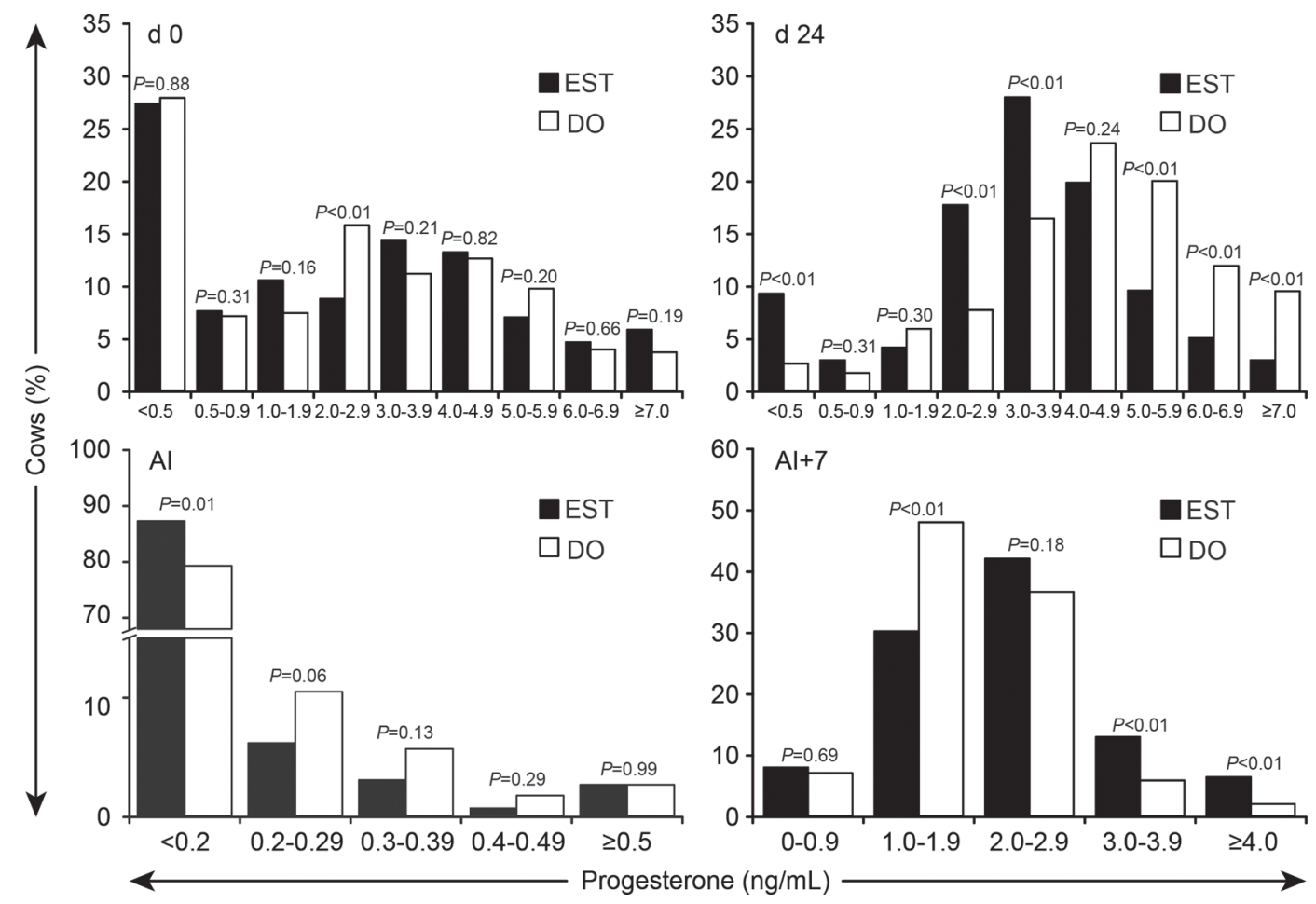

Figure 3. Effect of treatment on distribution of lactating Holstein cows based on progesterone concentrations at d 0 (upper left panel), at d 24 (upper right panel), at the time of insemination (lower left panel), and $7 \mathrm{~d}$ after insemination (lower right panel). DO = first insemination as a timed AI after a Double-Ovsynch protocol; EST = first insemination as an AI to a detected estrus after a protocol for synchronization of estrus.

$\mathrm{P} 4$ concentrations at $\mathrm{d} 0$ for EST cows not detected in estrus after the final $\mathrm{PGF}_{2 \alpha}$ treatment of the protocol for synchronization of estrus was $2.7 \mathrm{ng} / \mathrm{mL}$. Overall, only $38 \%$ of EST cows not detected in estrus at the end of the protocol had $\mathrm{P} 4$ concentrations $<0.5 \mathrm{ng} / \mathrm{mL}$. Thus, anovulatory status at the onset of the protocol did not fully account for failure of these cows to be detected in estrus at the end of the protocol. This is similar to findings of other studies that speculated that issues other than cyclicity status affected efficiency and accuracy of detection of estrus in lactating dairy cows submitted to a synchronization protocol (Chebel and Santos, 2010; Fricke et al., 2014). For cows with P4 $<1.0 \mathrm{ng} / \mathrm{mL}$ on $\mathrm{d} 0, \mathrm{P} /$ AI did not differ $(P=0.67)$ between treatments $[40.0 \%(40 / 100)$ vs. $36.7 \%(25 / 68)$, for DO vs. EST cows, respectively]; however, for cows with $\mathrm{P} 4 \geq 1.0 \mathrm{ng} / \mathrm{mL}$ on $\mathrm{d} 0$, DO cows had more $(P<$ $0.01) \mathrm{P} / \mathrm{AI}$ then EST cows [53.4\% (102/191) vs. $38.3 \%$ (57/149), respectively].

P4 at d 24. Overall, DO cows had greater P4 concentrations on d 24 than EST cows (Figure 3, upper right panel). On d 24, mean $\mathrm{P} 4$ concentration was 4.1 $\pm 0.1 \mathrm{ng} / \mathrm{mL}$, and mean $\mathrm{P} 4$ concentration was greater $(P<0.01)$ for DO cows than for EST cows $(4.6$ vs. 3.5 $\mathrm{ng} / \mathrm{mL}$, respectively). Mean $\mathrm{P} 4$ concentrations did not differ $(P=0.61)$ between primiparous and multiparous cows (4.0 vs. $4.1 \mathrm{ng} / \mathrm{mL}$, respectively). When cows were divided into 9 categories based on $\mathrm{P} 4$ concentrations at d 24 (Figure 3, upper right panel), more $(P$ $<0.01)$ EST cows had $\mathrm{P} 4<0.5 \mathrm{ng} / \mathrm{mL}$ than $\mathrm{DO}$ cows $[9.6 \%(26 / 271)$ vs. $2.8 \%(8 / 288)]$, and more $(P<0.01)$

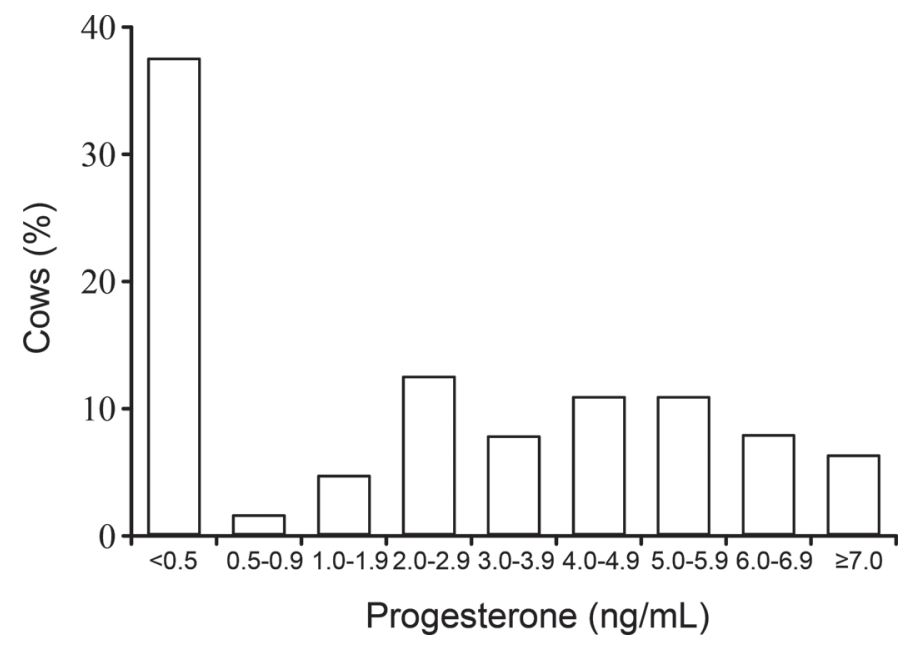

Figure 4. Distribution of lactating Holstein cows based on progesterone concentration on $\mathrm{d} 0$ for cows in the estrus treatment group not detected in estrus after a hormonal protocol for synchronization of estrus. 
DO cows had P4 $\geq 4.0 \mathrm{ng} / \mathrm{mL}$ than EST cows $[65.9 \%$ $(190 / 288)$ vs. $37.3 \%(101 / 271)$, respectively].

In the present study, DO cows should have greater P4 concentrations at d 24 than EST cows due to a treatment effect on CL number. A Double-Ovsynch protocol consists of 2 successive Ovsynch protocols; the first is the Pre-Ovsynch portion of the protocol, which is followed by the Breeding-Ovsynch portion of the protocol (Souza et al., 2008; Giordano et al., 2013). Although not assessed in our study, TAI cows ovulating after the last GnRH treatment of the Pre-Ovsynch portion of the protocol and at the first GnRH treatment of the Breeding-Ovsynch part of the protocol should have 2 CL at the $\mathrm{PGF}_{2 \alpha}$ treatment of the Breeding-Ovsynch portion of the protocol as reported in another study using the same Double-Ovsynch protocol (Fricke et al., 2016). By contrast, EST cows should have only 1 CL at this time during the protocol for synchronization of estrus. Progesterone concentrations before spontaneous or induced luteal regression are associated with $\mathrm{P} / \mathrm{AI}$ in both cows receiving TAI and cows receiving AI after a detected estrus. For example, Nebel et al. (1987) reported that $\mathrm{P} / \mathrm{AI}$ increased as $\mathrm{P} 4$ concentrations increased during the diestrus immediately preceding first AI for cows inseminated after a detected estrus. Similarly, in an analysis by Fricke et al. (2015) that evaluated the association between $\mathrm{P} 4$ concentrations at the time of the $\mathrm{PGF}_{2 \alpha}$ treatment in 3,383 TAI services, cows with low $\mathrm{P} 4$ concentrations at a similar point during a DoubleOvsynch protocol had 20\% P/AI compared with $41 \%$ $\mathrm{P} / \mathrm{AI}$ for cows with high $\mathrm{P} 4$ concentrations at this time.

$P 4$ at the Time of AI. Accuracy of detection of estrus has a profound effect on conception rates in dairy cows (Heersche and Nebel, 1994; Sturman et al., 2000); thus, accuracy of detection of estrus must be accounted for when assessing P/AI. Blood samples were collected at the time of AI to evaluate accuracy of detection of estrus for EST cows. Although the correct timing of AI cannot definitively be established for cows with low $\mathrm{P} 4$ at the time of $\mathrm{AI}$, these cows were inseminated in the absence of a functional CL, a stage of the cycle when estrus and ovulation should occur. By contrast, cows with high $\mathrm{P} 4$ near the time of AI had a functional $\mathrm{CL}$ and were inseminated at an incorrect stage of the cycle. Similarly, P/AI for cows submitted to a DoubleOvsynch protocol are profoundly affected by lack of complete luteal regression, and low $\mathrm{P} 4$ at TAI for DO cows is an indicator of luteal regression at this point during a Double-Ovsynch protocol (Brusveen et al., 2009; Fricke et al., 2015).

At the time of insemination, mean $\mathrm{P} 4$ concentration was $0.25 \pm 0.0 \mathrm{ng} / \mathrm{mL}$. Overall, DO cows had lower $(P=0.05) \mathrm{P} 4$ concentrations than EST cows (0.22 vs. $0.29 \mathrm{ng} / \mathrm{mL}$, respectively), but mean $\mathrm{P} 4$ concentra- tion at insemination did not differ $(P=0.93)$ between primiparous versus multiparous cows (0.26 vs. 0.25 $\mathrm{ng} / \mathrm{mL}$, respectively). When cows were divided into 5 categories based on $\mathrm{P} 4$ concentrations at insemination (Figure 3, lower left panel), more $(P=0.01)$ EST cows had P4 $<0.2 \mathrm{ng} / \mathrm{mL}$, whereas more DO cows had P4 concentrations between 0.2 and $0.39 \mathrm{ng} / \mathrm{mL}$. Nonetheless, the proportion of cows with $\mathrm{P} 4>0.4 \mathrm{ng} / \mathrm{mL}$ did not differ $(P=0.91)$ between treatments or parities $[P$ $=0.27 ; 2.6 \%(2 / 194)$ vs. $4.5 \%(14 / 311)$ for primiparous vs. multiparous cows, respectively].

$P 47 \boldsymbol{d}$ After $\boldsymbol{A I}$. As an additional indicator of accuracy of timing of insemination for cows in both treatments, blood samples were collected $7 \mathrm{~d}$ after insemination to determine if $\mathrm{P} 4$ increased for cows with low $\mathrm{P} 4$ at insemination. Overall, $7 \mathrm{~d}$ after AI, mean P4 concentration was $2.1 \pm 0.1 \mathrm{ng} / \mathrm{mL}$. Mean P4 concentration was greater $(P<0.01)$ for EST than for DO cows (2.3 vs. $1.9 \mathrm{ng} / \mathrm{mL}$, respectively), but mean $\mathrm{P} 4$ concentration $7 \mathrm{~d}$ after insemination did not differ $(P=$ $0.20)$ between primiparous and multiparous cows $(2.2$ vs. 2.1, respectively).

When cows were divided into 5 categories based on P4 concentrations $7 \mathrm{~d}$ after insemination, more $(P<$ $0.01)$ DO cows had $\mathrm{P} 4$ concentrations $<2.0 \mathrm{ng} / \mathrm{mL}$, whereas more $(P<0.01)$ EST cows had $\mathrm{P} 4 \geq 2.0 \mathrm{ng} /$ $\mathrm{mL}$ (Figure 3, lower right panel). The lower P4 distribution $7 \mathrm{~d}$ after insemination for DO cows is possibly due to smaller ovulatory follicles because preovulatory follicular size is positively correlated with P4 concentrations after ovulation (Vasconcelos et al., 2001). High-producing Holstein cows have increased hepatic metabolism of steroid hormones (Vasconcelos et al., 2003; Wiltbank et al., 2006). For cows ovulating spontaneously after luteolysis, the dominant follicle requires a longer period of growth for estradiol concentrations to exceed the threshold required to induce a $\mathrm{GnRH}$ surge from the hypothalamus, which subsequently induces an LH surge from the anterior pituitary, thereby resulting in ovulation of larger/older dominant follicles (Wiltbank et al., 2006). By contrast, cows submitted to a Double-Ovsynch protocol ovulate smaller follicles because the LH surge and ovulation is induced by the final exogenous $\mathrm{GnRH}$ treatment at the end of the protocol, which occurs earlier during development of a synchronized follicular wave (Cerri et al., 2009; Wiltbank and Pursley, 2014).

\section{Effect of Treatment and Synchrony to the Protocols on P/AI}

The effect of treatment and synchrony to the hormonal protocols on $\mathrm{P} / \mathrm{AI}$ was assessed for a subset of cows $(\mathrm{n}=490)$ in which we had a complete set of $\mathrm{P} 4$ 
Table 3. Effect of treatment on percentage (no./no.) of cows synchronized and effect of synchronization status on pregnancies per $\mathrm{AI}(\mathrm{P} / \mathrm{AI})$ of lactating Holstein cows

\begin{tabular}{|c|c|c|c|}
\hline \multirow[b]{2}{*}{ Item } & \multicolumn{2}{|c|}{ Treatment $^{1}$} & \multirow[b]{2}{*}{$P$-value } \\
\hline & DO & EST & \\
\hline \multicolumn{4}{|l|}{$\overline{\mathrm{P} 4^{2} \text { on } \mathrm{d} 24 \text { (i.e., at } \mathrm{PGF}_{2 \alpha} \text { ) }}$} \\
\hline Cows with $\mathrm{P} 4<0.5 \mathrm{ng} / \mathrm{mL}$ & $4.5(13 / 287)$ & $6.4(13 / 203)$ & 0.36 \\
\hline $\mathrm{P} / \mathrm{AI}$ for cows with $\mathrm{P} 4<0.5 \mathrm{ng} / \mathrm{mL}$ & $7.7(1 / 13)$ & $7.7(1 / 13)$ & 0.76 \\
\hline $\mathrm{P} / \mathrm{AI}$ for cows with $\mathrm{P} 4 \geq 0.5 \mathrm{ng} / \mathrm{mL}$ & $50.1(140 / 274)$ & $40.5(77 / 190)$ & 0.03 \\
\hline \multicolumn{4}{|l|}{$\mathrm{P} 4$ at insemination } \\
\hline Cows with $\mathrm{P} 4 \geq 0.4 \mathrm{ng} / \mathrm{mL}$ & $3.7(10 / 274)$ & $2.1(4 / 190)$ & 0.34 \\
\hline $\mathrm{P} / \mathrm{AI}$ for cows with $\mathrm{P} 4 \geq 0.4 \mathrm{ng} / \mathrm{mL}$ & $30.0(3 / 10)$ & $0.0(0 / 4)$ & 0.22 \\
\hline $\mathrm{P} / \mathrm{AI}$ for cows with $\mathrm{P} 4<0.4 \mathrm{ng} / \mathrm{mL}$ & $51.9(137 / 264)$ & $41.4(77 / 186)$ & 0.03 \\
\hline \multicolumn{4}{|l|}{ P4 7 d after AI } \\
\hline Cows with $\mathrm{P} 4<1.0 \mathrm{ng} / \mathrm{mL}$ & $7.2(19 / 264)$ & $7.0(13 / 186)$ & 0.93 \\
\hline $\mathrm{P} / \mathrm{AI}$ for cows with $\mathrm{P} 4<1.0 \mathrm{ng} / \mathrm{mL}$ & $15.8(3 / 19)$ & $0.0(0 / 13)$ & 0.13 \\
\hline $\mathrm{P} / \mathrm{AI}$ for cows with $\mathrm{P} 4 \geq 1.0 \mathrm{ng} / \mathrm{mL}$ & $54.7(134 / 245)$ & $44.5(77 / 173)$ & 0.04 \\
\hline \multicolumn{4}{|l|}{ Estrous cycle synchronization } \\
\hline Synchronized cows & $85.4(245 / 287)$ & $85.2(173 / 203)$ & 0.96 \\
\hline P/AI for cows not synchronized & $16.7(7 / 42)$ & $3.3(1 / 30)$ & 0.07 \\
\hline $\mathrm{P} / \mathrm{AI}$ for synchronized cows & $54.7(134 / 245)$ & $44.5(77 / 173)$ & 0.04 \\
\hline
\end{tabular}

${ }^{1}$ Each week, lactating Holstein cows at $50 \pm 3$ DIM (d 0) were stratified by parity (primiparous vs. multiparous) and were randomized to receive first insemination as a timed AI after a Double-Ovsynch (DO) protocol or AI to a detected estrus after a hormonal protocol that synchronized estrus (EST).

${ }^{2} \mathrm{P} 4=$ progesterone.

samples collected at d 24 (i.e., at the time of $\mathrm{PGF}_{2 \alpha}$ ), at the time of insemination, and $7 \mathrm{~d}$ after insemination (Table 3). Synchrony to the hormonal synchronization protocols was defined as cows with high $\mathrm{P} 4$ (i.e., $>0.5$ $\mathrm{ng} / \mathrm{mL}$ ) on d 24 (Figure 1), low $\mathrm{P} 4(<0.4 \mathrm{ng} / \mathrm{mL})$ at insemination, and high $\mathrm{P} 4(\geq 1.0 \mathrm{ng} / \mathrm{mL}) 7 \mathrm{~d}$ after insemination. Using a similar methodology to other experiments (Giordano et al., 2012; Lopes et al., 2013; Carvalho et al., 2014a), P/AI of synchronized versus nonsynchronized cows was compared, and nonsynchronized cows were removed in a stepwise manner before making the same comparison at the next time point during the protocols.

The percentage of cows with $\mathrm{P} 4<0.5 \mathrm{ng} / \mathrm{mL}$ on $\mathrm{d}$ 24 was $5.3 \%(26 / 490)$ and did not differ between treatments (Table 3 ). Overall, $\mathrm{P} / \mathrm{AI}$ for cows with $\mathrm{P} 4<0.5$ $\mathrm{ng} / \mathrm{mL}$ was $7.7 \%(2 / 26)$ and did not differ between treatments; however, for cows with $\mathrm{P} 4 \geq 0.5 \mathrm{ng} / \mathrm{mL}$, DO cows had more $(P=0.03) \mathrm{P} /$ AI than EST cows (50.1 vs. $40.5 \%$ ). After removal of cows with P4 $0.5 \mathrm{ng} /$ $\mathrm{mL}$ at $\mathrm{d} 24$, the percentage of cows with $\mathrm{P} 4 \geq 0.4 \mathrm{ng} /$ $\mathrm{mL}$ at the time of insemination was $3.0 \%(14 / 464)$ and did not differ between treatments. For cows with P4 $\geq 0.4 \mathrm{ng} / \mathrm{mL}$ near the time of insemination, $\mathrm{P} / \mathrm{AI}$ was $21.4 \%(3 / 14)$, and did not differ between treatments; however, for cows with $\mathrm{P} 4<0.4 \mathrm{ng} / \mathrm{mL}$ at the time of insemination, DO cows had more $(P=0.03) \mathrm{P} / \mathrm{AI}$ than EST cows (51.9 vs. $41.4 \%)$. Cows with $\mathrm{P} 4>0.5 \mathrm{ng} / \mathrm{mL}$ on $\mathrm{d} 24$ and $\mathrm{P} 4<0.4 \mathrm{ng} / \mathrm{mL}$ at the time of insemination were further analyzed for $\mathrm{P} 47 \mathrm{~d}$ after insemination. The percentage of cows with $\mathrm{P} 4<1.0 \mathrm{ng} / \mathrm{mL} 7$ d after insemination was $7.1 \%(32 / 450)$ and did not differ between treatments. For cows with $\mathrm{P} 4<1.0 \mathrm{ng} /$ $\mathrm{mL}, \mathrm{P} / \mathrm{AI}$ was $9.4 \%(3 / 32)$ and did not differ between treatments; however, for cows with $\mathrm{P} 4 \geq 1.0 \mathrm{ng} / \mathrm{mL} 7 \mathrm{~d}$ after insemination, DO cows had more $(P=0.04) \mathrm{P} / \mathrm{AI}$ than EST cows (54.7 vs. $44.5 \%$ ). The analysis in Table 3 resulted in an overall synchronization rate of $85.3 \%$, which did not differ between treatments. Overall P/AI for cows considered not synchronized was $11.1 \%$ (8/72); however, for cows that were considered synchronized, $23 \%$ more $(P=0.04)$ DO cows were pregnant $33 \mathrm{~d}$ after insemination than EST cows (54.7 vs. $44.5 \%$ ).

Synchronization rate measured by response to each of the sequential hormonal treatments within a TAI protocol has a profound effect on $\mathrm{P} / \mathrm{AI}$, and differences in $\mathrm{P} / \mathrm{AI}$ to TAI between protocols have been attributed to differences in the proportion of cows considered synchronized using a similar methodological approach to that used in the present study (Giordano et al., 2012; Lopes et al., 2013; Carvalho et al., 2014a). The results of the synchronization analysis in Table 3 support that the effect of treatment on $\mathrm{P} / \mathrm{AI}$ was not due to a difference in synchronization rate, but rather resulted from a $23 \%$ increase in P/AI $33 \mathrm{~d}$ after insemination for DO than for EST cows. Thus, because the proportion of synchronized cows did not differ between treatments, DO cows had more P/AI than EST cows because of an intrinsic increase in fertility suggesting that inseminating high-producing Holstein cows after a detected estrus results in lower fertility than when cows receive TAI after submission to a fertility program. 
The specific physiological mechanisms by which Double-Ovsynch and TAI increases fertility in highproducing Holstein cows was not assessed in the present study. Cerri et al. (2009) evaluated embryos flushed from cows inseminated after an induced estrus and cows submitted to TAI after a Double-Ovsynch protocol at a similar DIM. Treatment did not affect fertilization rate ( 89 vs. $88 \%$, for cows inseminated after an induced estrus versus cows receiving TAI after a Double-Ovsynch protocol); however, the percentage of embryos classified as degenerated was greater for cows inseminated after an induced estrus than for cows submitted to TAI after a Double-Ovsynch protocol (24 vs. 5\%). Therefore, it is possible that increased $\mathrm{P} 4$ concentrations during growth of the dominant follicle coupled with ovulation of smaller dominant follicles when cows are submitted to TAI after a Double-Ovsynch protocol increased embryo quality resulting in more $\mathrm{P} / \mathrm{AI}$ than when cows were inseminated after a detected estrus (Wiltbank et al., 2011a,b). In addition, timing of insemination relative to ovulation is more precise when cows are submitted to a synchronization protocol than when they are inseminated after a detected estrus (Valenza et al., 2012).

\section{ACKNOWLEDGMENTS}

We thank the owners and farm personnel of Demeco Agro Pecuaria farm (Evora, Portugal) for allowing us access to their cows and facilities to conduct this study. We also thank Ceva Santé Animale (Libourne, France) for donation of the Ovarelin, Enzaprost-T, and PRID Delta devices, and to Accelerated Genetics (Baraboo, WI) for donation of the semen. This work was partially funded by Ceva Santé Animale from which P.M.F. has received honoraria for speaking at meetings for veterinarians. This work was also partially funded by the USDA National Institute of Food and Agriculture (Washington, DC), Hatch project 1006519 to P. M. Fricke.

\section{REFERENCES}

Bamber, R. L., G. E. Shook, M. C. Wiltbank, J. E. P. Santos, and P. M. Fricke. 2009. Genetic parameters for anovulation and pregnancy loss in dairy cattle. J. Dairy Sci. 92:5739-5753.

Bello, N. M., J. P. Steibel, and J. R. Pursley. 2006. Optimizing ovulation to first GnRH improved outcomes to each hormonal injection of Ovsynch in lactating dairy cows. J. Dairy Sci. 89:3413-3424.

Borchardt, S., P. Haimerl, and W. Heuwieser. 2016. Effect of insemination after estrous detection on pregnancy per artificial insemination and pregnancy loss in a Presynch-Ovsynch protocol: A metaanalysis. J. Dairy Sci. 99:2248-2256.

Brusveen, D. J., A. H. Souza, and M. C. Wiltbank. 2009. Effects of additional prostaglandin F2 $\alpha$ and estradiol-17 $\beta$ during Ovsynch in lactating dairy cows. J. Dairy Sci. 92:1412-1422.
Buch, N. C., W. J. Tyler, and L. E. Casida. 1955. Postpartum estrus and involution of the uterus in an experimental herd of HolsteinFriesian cows. J. Dairy Sci. 38:73-79.

Caraviello, D. Z., K. A. Weigel, P. M. Fricke, M. C. Wiltbank, M. J. Florent, N. B. Cook, K. V. Nordlund, N. R. Zwald, and C. L. Rawson. 2006. Survey of management practices on reproductive performance of dairy cattle on large US commercial farms. J. Dairy Sci. 89:4723-4735.

Carvalho, P. D., M. J. Fuenzalida, A. Ricci, A. H. Souza, R. Barletta, M. C. Wiltbank, and P. M. Fricke. 2015a. Modifications of Ovsynch improve fertility during resynchronization: Evaluation of presynchronization with gonadotropin-releasing hormone $6 \mathrm{~d}$ before initiation of Ovsynch and addition of a second prostaglandin $\mathrm{F}_{2 \alpha}$ treatment. J. Dairy Sci. 98:8741-8752.

Carvalho, P. D., J. N. Guenther, M. J. Fuenzalida, M. C. Amundson, M. C. Wiltbank, and P. M. Fricke. 2014a. Presynchronization using a modified Ovsynch protocol or a single gonadotropin-releasing hormone injection $7 \mathrm{~d}$ before an Ovsynch-56 protocol for submission of lactating dairy cows to first timed artificial insemination. J. Dairy Sci. 97:6305-6315.

Carvalho, P. D., A. H. Souza, M. C. Amundson, K. S. Hackbart, M. J. Fuenzalida, M. M. Herlihy, H. Ayres, A. R. Dresch, L. M. Vieira, J. N. Guenther, R. R. Grummer, P. M. Fricke, R. D. Shaver, and M. C. Wiltbank. 2014b. Relationships between fertility and postpartum changes in body condition and body weight in lactating dairy cows. J. Dairy Sci. 97:3666-3683.

Carvalho, P. D., M. C. Wiltbank, and P. M. Fricke. 2015b. Manipulation of progesterone to increase ovulatory response to the first GnRH treatment of an Ovsynch protocol in lactating dairy cows receiving first timed artificial insemination. J. Dairy Sci. 98:88008813.

Cerri, R. L. A., H. M. Rutigliano, R. C. Chebel, and J. E. P. Santos. 2009. Period of dominance of the ovulatory follicle influences embryo quality in lactating dairy cows. Reproduction 137:813-823.

Chebel, R. C., and J. E. P. Santos. 2010. Effect of inseminating cows in estrus following a presynchronization protocol on reproductive and lactation performances. J. Dairy Sci. 93:4632-4643.

Dolecheck, K. A., W. J. Silvia, G. Heersche Jr., C. L. Wood, K. J. McQuerry, and J. M. Bewley. 2016. A comparison of timed artificial insemination and automated activity monitoring with hormone intervention in 3 commercial dairy herds. J. Dairy Sci. 99:1506-1514.

Ferguson, J. D., D. T. Galligan, and N. Thomsen. 1994. Principal descriptors of body condition score in Holstein cows. J. Dairy Sci. 77:2695-2703

Fricke, P. M., P. D. Carvalho, M. C. Lucy, F. Curran, M. M. Herlihy, S. M. Waters, J. A. Larkin, M. A. Crowe, and S. T. Butler. 2016. Effect of manipulating progesterone before timed artificial insemination on reproductive and endocrine parameters in seasonal-calving pasture-based Holstein-Friesian cows. J. Dairy Sci. 99:6780-6792.

Fricke, P. M., J. O. Giordano, A. Valenza, G. Lopes Jr., M. C. Amundson, and P. D. Carvalho. 2014. Reproductive performance of lactating dairy cows managed for first service using timed artificial insemination with or without detection of estrus using an activitymonitoring system. J. Dairy Sci. 97:2771-2781.

Fricke, P. M., M. C. Wiltbank, P. D. Carvalho, and J. O. Giordano. 2015. Fertility programs to achieve high 21-d pregnancy rates in high-producing Holstein dairy herds. Pages 15-27 in Proc. Dairy Cattle Reprod. Counc. Conf. Dairy Cattle Reproduction Council, Buffalo, NY.

Giordano, J. O., M. C. Wiltbank, P. M. Fricke, S. Bas, R. Pawlisch, J. N. Guenther, and A. B. Nascimento. 2013. Effect of increasing GnRH and PGF2 $\alpha$ dose during Double-Ovsynch on ovulatory response, luteal regression, and fertility of lactating dairy cows. Theriogenology 80:773-783.

Giordano, J. O., M. C. Wiltbank, J. N. Guenther, R. Pawlisch, S. Bas, A. P. Cunha, and P. M. Fricke. 2012. Increased fertility in lactating dairy cows resynchronized with Double-Ovsynch compared with Ovsynch initiated $32 \mathrm{~d}$ after timed artificial insemination. J. Dairy Sci. 95:639-653. 
Gümen, A., J. N. Guenther, and M. C. Wiltbank. 2003. Follicular size and response to Ovsynch versus detection of estrus in anovular and ovular lactating dairy cows. J. Dairy Sci. 86:3184-3194.

Gumen, A., A. Keskin, G. Yilmazbas-Mecitoglu, E. Karakaya, A. Alkan, H. Okut, and M. C. Wiltbank. 2012. Effect of presynchronization strategy before Ovsynch on fertility at first service in lactating dairy cows. Theriogenology 78:1830-1838.

Heersche, G., and R. L. Nebel. 1994. Measuring efficiency and accuracy of detection of estrus. J. Dairy Sci. 77:2754-2761.

Lopes, G., Jr., J. O. Giordano, A. Valenza, M. M. Herlihy, J. N. Guenther, M. C. Wiltbank, and P. M. Fricke. 2013. Effect of timing of initiation of resynchronization and presynchronization with gonadotropin-releasing hormone on fertility of resynchronized inseminations in lactating dairy cows. J. Dairy Sci. 96:3788-3798.

Miller, R. H., H. D. Norman, M. T. Kuhn, J. S. Clay, and J. L. Hutchison. 2007. Voluntary waiting period and adoption of synchronized breeding in dairy herd improvement herds. J. Dairy Sci. 90:1594-1606.

Moreira, F., C. Orlandi, C. A. Risco, R. Mattos, F. Lopes, and W. W. Thatcher. 2001. Effects of presynchronization and bovine somatotropin on pregnancy rates to a timed artificial insemination protocol in lactating dairy cows. J. Dairy Sci. 84:1646-1659.

Navanukraw, C., D. A. Redmer, L. P. Reynolds, J. D. Kirsch, A. T. Grazul-Bilska, and P. M. Fricke. 2004. A modified presynchronization protocol improves fertility to timed artificial insemination in lactating dairy cows. J. Dairy Sci. 87:1551-1557.

Nebel, R. L., W. D. Whittier, B. G. Cassell, and J. H. Britt. 1987. Comparison of on-farm and laboratory milk progesterone assays for identifying errors in detection of estrus and diagnosis of pregnancy. J. Dairy Sci. 70:1471-1476.

Norman, H. D., J. R. Wright, S. M. Hubbard, R. H. Miller, and J. L. Hutchison. 2009. Reproductive status of Holstein and Jersey cows in the United States. J. Dairy Sci. 92:3517-3528.

NRC. 2001. Nutrient Requirements of Dairy Cattle. 7th rev. ed. The National Academies Press, Washington, DC.

Pursley, J. R., M. R. Kosorok, and M. C. Wiltbank. 1997. Reproductive management of lactating dairy cows using synchronization of ovulation. J. Dairy Sci. 80:301-306.

Pursley, J. R., M. O. Mee, and M. C. Wiltbank. 1995. Synchronization of ovulation in dairy cows using PGF $2 \alpha$ and GnRH. Theriogenology 44:915-923.

Ribeiro, E. S., R. L. A. Cerri, R. S. Bisinotto, F. S. Lima, F. T. Silvestre, L. F. Greco, W. W. Thatcher, and J. E. P. Santos. 2011. Reproductive performance of grazing dairy cows following presynchronization and resynchronization protocols. J. Dairy Sci. 94:4984-4996.

Santos, J. E. P., W. W. Thatcher, R. C. Chebel, R. L. A. Cerri, and K. N. Galvão. 2004. The effect of embryonic death rates in cattle on the efficacy of estrus synchronization programs. Anim. Reprod. Sci. 82-83:513-535.
Santos, V. G., P. D. Carvalho, C. Maia, B. Carneiro, A. Valenza, P. M. Crump, and P. M. Fricke. 2016. Adding a second prostaglandin F2 $\alpha$ treatment to but not reducing the duration of a PRID-Synch protocol increases fertility after resynchronization of ovulation in lactating Holstein cows. J. Dairy Sci. 99:3869-3879.

Silva, E., R. A. Sterry, D. Kolb, M. C. Wiltbank, and P. M. Fricke. 2007. Effect of pretreatment with prostaglandin F2 $\alpha$ before resynchronization of ovulation on fertility of lactating dairy cows. J. Dairy Sci. 90:5509-5517.

Souza, A. H., H. Ayres, R. M. Ferreira, and M. C. Wiltbank. 2008. A new presynchronization system (Double-Ovsynch) increases fertility at first postpartum timed AI in lactating dairy cows. Theriogenology 70:208-215.

Stevenson, J. S., S. L. Hill, R. L. Nebel, and J. M. DeJarnette. 2014 Ovulation timing and conception risk after automated activity monitoring in lactating dairy cows. J. Dairy Sci. 97:4296-4308.

Sturman, H., E. A. B. Oltenacu, and R. H. Foote. 2000. Importance of inseminating only cows in estrus. Theriogenology 53:1657-1667.

Valenza, A., J. O. Giordano, G. Lopes Jr., L. Vincenti, M. C. Amundson, and P. M. Fricke. 2012. Assessment of an accelerometer system for detection of estrus and treatment with gonadotropin-releasing hormone at the time of insemination in lactating dairy cows. J. Dairy Sci. 95:7115-7127.

Vasconcelos, J. L. M., S. Sangsritavong, S. J. Tsai, and M. C. Wiltbank. 2003. Acute reduction in serum progesterone concentrations after feed intake in dairy cows. Theriogenology 60:795-807.

Vasconcelos, J. L. M., R. Sartori, H. N. Oliveira, J. G. Guenther, and M. C. Wiltbank. 2001. Reduction in size of the ovulatory follicle reduces subsequent luteal size and pregnancy rate. Theriogenology $56: 307-314$.

Wiltbank, M., H. Lopez, R. Sartori, S. Sangsritavong, and A. Gümen. 2006. Changes in reproductive physiology of lactating dairy cows due to elevated steroid metabolism. Theriogenology 65:17-29.

Wiltbank, M. C., G. M. Baez, F. Cochrane, R. V. Barletta, C. R. Trayford, and R. T. Joseph. 2015. Effect of a second treatment with prostaglandin F2 $\alpha$ during the Ovsynch protocol on luteolysis and pregnancy in dairy cows. J. Dairy Sci. 98:8644-8654.

Wiltbank, M. C., and J. R. Pursley. 2014. The cow as an induced ovulator: Timed AI after synchronization of ovulation. Theriogenology 81:170-185.

Wiltbank, M. C., R. Sartori, M. M. Herlihy, J. L. M. Vasconcelos, A. B. Nascimento, A. H. Souza, H. Ayres, A. P. Cunha, A. Keskin, J. N. Guenther, and A. Gumen. 2011a. Managing the dominant follicle in lactating dairy cows. Theriogenology 76:1568-1582.

Wiltbank, M. C., A. H. Souza, P. D. Carvalho, R. W. Bender, and A. B. Nascimento. 2011b. Improving fertility to timed artificial insemination by manipulation of circulating progesterone concentrations in lactating dairy cattle. Reprod. Fertil. Dev. 24:238-243. 